\title{
スピネル型フェライト薄膜電極の酸素過電圧 と磁性との相関
}

岩含一秋, 西岡正人, 田村英雄

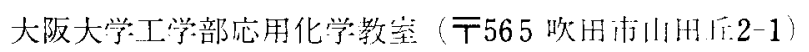

電極の磁性と反応速度論の関係についてはあまり報告 されていない. 最近, Srinivasan らは $\mathrm{Ni}$ 電極上での 酸素発生反応に扔いて $\mathrm{NiO}$ が反強磁性から常磁性状態 に転移する N'eel 温度付近で Tafelこう配すなわち移 動倸数が変化することを見い出し"，続いて $\mathrm{NiCu}$ 電極 上での酸素発生反応に拉いても強磁性から常磁性状態に 転移するCurie 温度付近で移動係数が変化することを 報告している2).しかしながら,移動係数ならびに電気化 学的触媒活性は Ni 電極で注常磁性状態となる N'eel 温 度以上で大きく, $\mathrm{NiCu}$ 電極では強磁性状態にある Curie 温度以上で大きいという対称的な結果となっていること やフェリ磁性の $\mathrm{Ni}_{x} \mathrm{Fe}_{3-x} \mathrm{O}_{4}$ 電極では移動係数と室温飽 和磁化ならびに組成との間に何ら系統的な関倸が認めら れないと報告している゙)ことなど，電極の磁性と反応速 度論の関連性についてはなお不明な点が多い，本報では スピネル型フェライト薄膜電極の酸素過電玨と磁性との

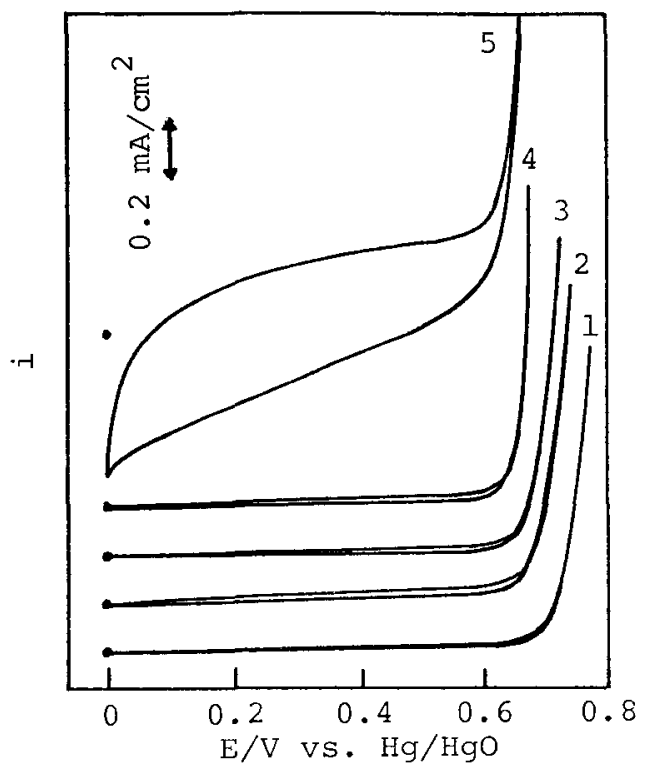

Fig.l Cyclic voltamograms for $\mathrm{Fe} / \mathrm{MFe}_{2} \mathrm{O}_{4}$ electrodes in $1 \mathrm{M} \mathrm{KOH}$ at $30^{\circ} \mathrm{C}$. Sweep rate: $10 \mathrm{mV} / \mathrm{sec}$
1) $\mathrm{Fe} / \mathrm{MgFe}_{2} \mathrm{O}_{4}$,
2) $\mathrm{Fe} / \mathrm{CuFe}_{2} \mathrm{O}_{4}$,
3) $\mathrm{Fe} / \mathrm{NiFe}_{2} \mathrm{O}_{4}$,
4) $\mathrm{Fe} / \mathrm{CoFe}_{2} \mathrm{O}_{4}$,
5) $\mathrm{Fe} / \mathrm{MnFe}_{2} \mathrm{O}_{4}$

相関について述べる.

試験電極は所定の化学量論比に混合した条種金属硝酸 塩水溶液を平滑 Fe 基板上に塗布 L, $500{ }^{\circ} \mathrm{C}$ で熱分解す ることによって作成した：X線回折実娩によりこれらの 電極の酸化物層恃純粋で俚なく，スピネル相以外に少量 の $\alpha-\mathrm{Fe}_{2} \mathrm{O}_{3}$ なども含まれていることがわかったが，以 後, 電極快 $\mathrm{Fe} / \mathrm{MF}_{2} \mathrm{O}_{4}(\mathrm{M}=\mathrm{Mg}, \mathrm{Cu}, \mathrm{Ni}, \mathrm{Co}, \mathrm{Mn}) \sigma$ ように表わ寸ことにする。

1. $\mathrm{M} \mathrm{KOH}$ 中, $30^{\circ} \mathrm{C}$ に抢什方各電極のサイクリックボ ルタングラムを Fig. 1 に示す.こ机5は $\mathrm{Hg} / \mathrm{HgO}$ 電 極基準で $0 \mathrm{~V}$ から電位をアノード方向に $10 \mathrm{mV} / \mathrm{sec} た ゙$ 走査し, 電流がはほ $1 \mathrm{~mA} / \mathrm{cm}^{2}$ になる電位でカソード 万向に折り返し走查することによって得たものである。 いずれの電極の場合にも非常に安定で再現性の良いボル タングラムが得られた。この結果から,酸素過電圧は $\mathrm{Fe} /$ $\mathrm{MgFe}_{2} \mathrm{O}_{4}>\mathrm{Fe} / \mathrm{CuFe}_{2} \mathrm{O}_{4}>\mathrm{Fe} / \mathrm{NiFe}_{2} \mathrm{O}_{4}>\mathrm{Fe} / \mathrm{CoFe}_{2} \mathrm{O}_{4}>$ $\mathrm{Fe} / \mathrm{MnFe}_{2} \mathrm{O}_{4}$ の順に低下しているこレがわかる。これら

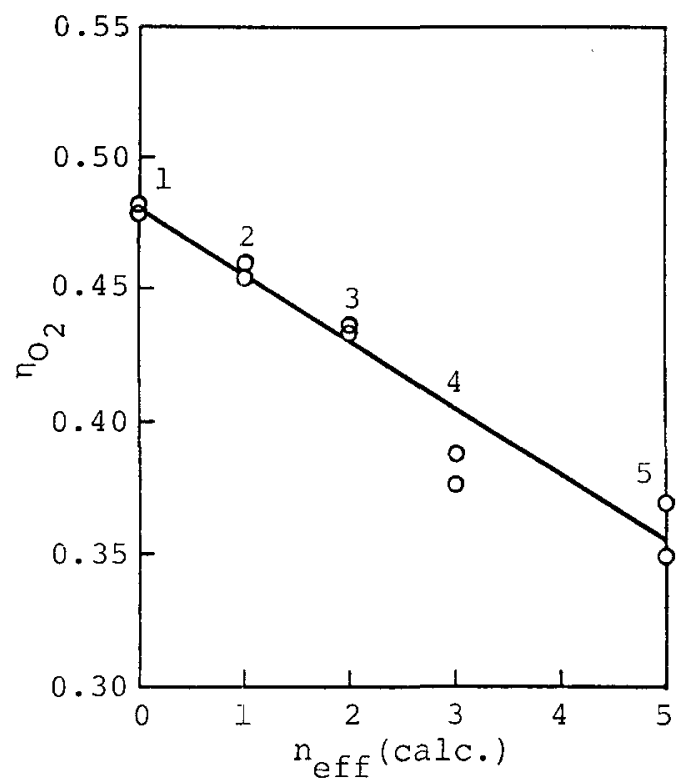

Fig.2 Plot of oxygen overvoltage at $1 \mathrm{~mA} / \mathrm{cm}^{2}, \mathrm{n}_{\mathrm{O}_{2}}$, against calculated effective Bohr magneton, $n_{\text {eff (calc.). Notations }}$ as in Fig. 1 


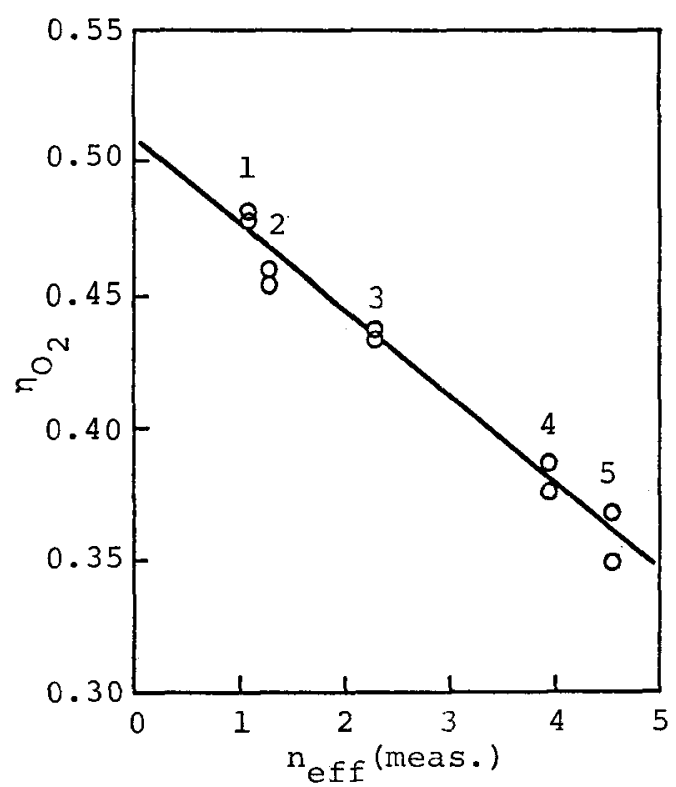

Fig.3 Plot of oxygen overvoltage at $1 \mathrm{~mA} / \mathrm{cm}^{2}, n_{\mathrm{O}_{2}}$, against measured effective Bôhr magneton, $n_{\text {eff }}$ (meas.). Notations as in Fig.l

の $1 \mathrm{~mA} / \mathrm{cm}^{2}$ に抢ける酸素過電圧, $\eta_{\mathrm{O}_{2}}$, の值をつェラ イトの有効 Bohr 磁子数, $n_{\mathrm{err}}$ の計算值执よび実測値 ${ }^{4,53}$ に対してプロットすると，それぞれ Fig. 2 および Fig. 3 に示すように，いずれも比較的良好な直線関係が得られ た. すなわち, 有効 Bohr 磁子数の堌大にっれて酸素過
電圧は減少し, 電気化学的触媒活性は増大寸る。この場 合, 有勃 Bohr 磁子数は 1 分子あたりの不対 $\mathrm{d}$ 電子の数 に対応しているので，もし検討したすべての電極上での 酸素発生反応が最初の水素イオンの放電が律速となる機 構で谁行するならば，不対 $\mathrm{d}$ 電子数の増加につれて生成 系の水酸ラジカルが安定化するために反応が容易になる と考えることにより Fig. 2 抢よび Fig. 3 の結果を説明 することが可能である。

以上で述べたよらに酸素過電圧と磁性との問に比較的 良好な相関が認められたが，本研究で用いた電極の酸化 物層が純粋なフェライトでないことや採用した有効 Bohr 磁子数の值が文献值であって本研究で実際に使用した電 極についての測定值でないことなど，さらに検討すべき 問題点が多く残されている.

\section{文献}

1) M.H.Miles, G. Kissel, P.W.T.Lu and S. Srinivasan, J. Electrochem. Soc. 123, 332 (1976).

2) J. Orehotsky, H. Huang, C.R. Davidson and S. Srinivasan, J. Electroanal. Chem. 95, 229 (1979).

3) J. Orehotsky, H. Huang, C. R. Davidson and S. Srinivasan, J. Electroanal. Chem. 95, 233 (1979)

4) 日本化学会編, “化学便覽”, p. 1239 (1975), 丸善.

5) D. J.Craik, "Magnetic Oxides" (Part 1), Ed. by D. J. Craik, p. 30 (1975), John Wiley \& Sons, London.

(Received May 23, 1981; Accepted Jun. 4, 1981) 